\title{
Metody imitatorskie uzupełniania dekoracji emalierskiej - scalenie kolorystyczne
}

\author{
ARLETTA PIASECKA \\ Zakład Konserwacji Elementów i Detali Architektonicznych, \\ Wydział Sztuk Pięknych, UMK w Toruniu \\ e-mail: arlettapiasecka@umk.pl \\ ANDRZEJ PODGÓRSKI \\ Zakład Konserwacji Elementów i Detali Architektonicznych, \\ Wydział Sztuk Pięknych, UMK w Toruniu \\ e-mail: andi@umk.pl \\ ALINA TOMASZEWSKA-SZEWCZYK \\ Zakład Konserwacji Elementów i Detali Architektonicznych, \\ Wydział Sztuk Pięknych, UMK w Toruniu \\ e-mail: alina.tomaszewska-szewczyk@umk.pl
}

Keywords: enamel, conservation, colour unification, retouch

Słowa kluczowe: emalie, konserwacja, unifikacja kolorystyczna, retusz

\begin{abstract}
Imitative methods to the fill the losses of the enamel decoration - retouching of colour

To the colour unification, at the reconstruction of decorative layer, various types of coloured film-forming products are used. They should be characterizing by excellent colour stability and good adhesion to the substrate. Colour stability of the coating depends on the chemical nature of the binder, of pigment or organic dye. Pigments or dyes must be soluble or should be compatible with the binder. Dimensions of the filler particles must be smaller than the wavelength of visible radiation (380-780 nm), so
\end{abstract}


they don't be scatter the light. In that case, even in small amounts, may give coloured coating with partial transparency. Pigments also may act as shielding materials for the deeper layer of macromolecular coating. This is a result of UV absorption only in the near-surface layer of the coating and barrier effect. Commercial, decorative paints, useful at conservation and restoration, based on natural resin e.g. mastic or on synthetic resins - acrylic, alkyd, ketone. This work shows the selected results obtained from laboratory tests of film-forming products made on the basis of various macromolecular binders.

\begin{abstract}
Abstrakt
Do wykonania unifikacji kolorystycznej w imitatorskim uzupełnianiu dekoracji emalierskiej stosowane są barwne wyroby powłokotwórcze, które powinny cechować się znakomitą stabilnością barwy i dobrą adhezją do podłoża. Stabilność barwnej powłoki uzależniona jest od chemicznej natury spoiwa, ale także pigmentu lub barwnika. Środki barwiące powinny być albo związkami rozpuszczalnymi w spoiwie, albo ze sobą kompatybilnymi, albo być tak rozdrobnione, ażeby nie rozpraszać światła. Wymiary drobin napełniaczy mniejsze niż długości fali (380-780 nm) nawet w niewielkich ilościach nadają barwę spoiwom, zachowując przy tym częściową ich transparentność. Pigmenty mogą także pełnić funkcję substancji ekranujących, chroniących spoiwo wielkocząsteczkowe przed szkodliwym działaniem światła z zakresu ultrafioletu. Jest to wynik pochłaniania promieniowania w warstwie przypowierzchniowej powłoki oraz tzw. efektu barierowego. Dostępne na rynku preparaty handlowe stosowane w konserwaji bazują na spoiwach pochodzenia naturalnego, takich jak mastyks, bądź na syntetycznych polimerach: akrylowych, alkidowych, ketonowych. W pracy przedstawiono wybrane wyniki badań laboratoryjnych preparatów powłokotwórczych sporządzonych na bazie różnych spoiw wielkocząsteczkowych.
\end{abstract}

\title{
Teoria koloru*
}

Przez pojęcie barwy należy rozumieć subiektywne wrażenie psychiczne, które powstaje w mózgu dzięki postrzeganiu zmysłowemu odbieranemu przez fotoreceptory: czopki i pręciki znajdujące się w zewnętrznej warstwie siatkówki oka, gdy trafiają do niego fale elektromagnetyczne z zakresu widzialnego, mieszczące się w tzw. oknie optycznym, czyli dla człowieka w przybliżeniu o długości 380-780 nm (opowiada to światłu od barwy fioletowej do czerwonej). Czopki umożliwiają postrzeganie barw przy dobrym oświetleniu (wi-

Janina Gronowska, Podstawy fizykochemii barwników (Toruń: Wydawnictwo UMK, 1989), 8-27; Jacek Tarasiuk, Problemy barwy i koloru, home.agh.edu.pl/ tarasiuk/dydaktyka/doc/ GFK/S/03.pdf, Dostęp 20 marca 2017. 
dzenie fotopowe), wychwytywanie szczegółów, a także odbieranie ruchu, co związane jest z szybkością ich reakcji na bodźce. Wrażenie barwy odbieranej przez człowieka zależy od składu widma światła docierającego do siatkówki, która według teorii Younga-Helmoltza ma trzy rodzaje czopków o innej charakterystyce widmowej, zależnej od budowy cząsteczek fotopsyn znajdujących się w błonie komórkowej neuronów. Różnica między ich wzbudzeniem odpowiada barwie, suma zaś jasności. Najlepsze widzenie uzyskujemy przy natężeniu światła na poziomie około 20 tysięcy luksów. Przy bardzo niskim poziomie oświetlenia, gdy czopki przestają funkcjonować, działanie przejmują wysoce czułe, reagujące nawet na pojedynczy foton pręciki. Odpowiadają one za widzenie zmierzchowe (skotopowe). Charakterystyczna dla niego jest zmiana w subiektywnym postrzeganiu jasności barw: te o krótkiej długości fali (niebieskie lub niebieskozielone) są postrzegane jako jaśniejsze od tych o długiej fali (czerwone, żółte). Przy natężeniu światła od 3 do 5 luksów barwę czerwoną odbieramy jako czarną. Zjawisko to zostało opisane w 1825 roku przez czeskiego fizjologa Johanna Evangelistę Purkinjego i nazywane jest przesunięciem (objawem) efektem Purkinjego.

Z percepcją barwy nierozerwalnie łączy się pojęcie koloru. Materia selektywnie absorbuje promieniowanie elektromagnetyczne, czyli pochłania światło o ściśle zdefiniowanej długości fal. Odbitą od niej część (spektrum) postrzegamy jako barwę. Kolor - cecha materii - jest wielkością mierzalną, natomiast pomiarem nie zdoła się oddać subiektywnego wrażenia barwy.

Subiektywność odczucia polega na tym, że w zależności od różnych czynników, takich jak towarzystwo innych kolorów, ich kontrast bądź różne oświetlenie, identyczna kombinacja fal może być postrzegana odmienne, natomiast bodźce świetlne różniące się rozkładem spektralnym mogą wywoływać to samo wrażenie barwne. Zjawisko to, nazywane metameryzmem, wynika między innymi z ograniczonej rozdzielności barwnej ludzkiego oka, które nie analizuje fizycznego składu spektralnego światła. Następuje zaś silna redukcja informacji. Barwa jest więc wrażeniem wzrokowym powstającym wskutek oddziaływania w określonych warunkach fali świetlnej z materią, a jego rodzaj będzie zależeć od cech fizycznych fali świetlnej, zjawisk fizjologicznych zachodzących pod wpływem światła oraz zjawisk psychologicznych.

Charakterystykę koloru opisuje się za pomocą trzech parametrów fizycznych (tab. 1): są nimi odcień (ang. hue), nasycenie (ang. saturtion) i jaskrawość (ang. brightness). 
Tabela 1. Charakterystyka percepcji koloru definiowanej trzema parametrami

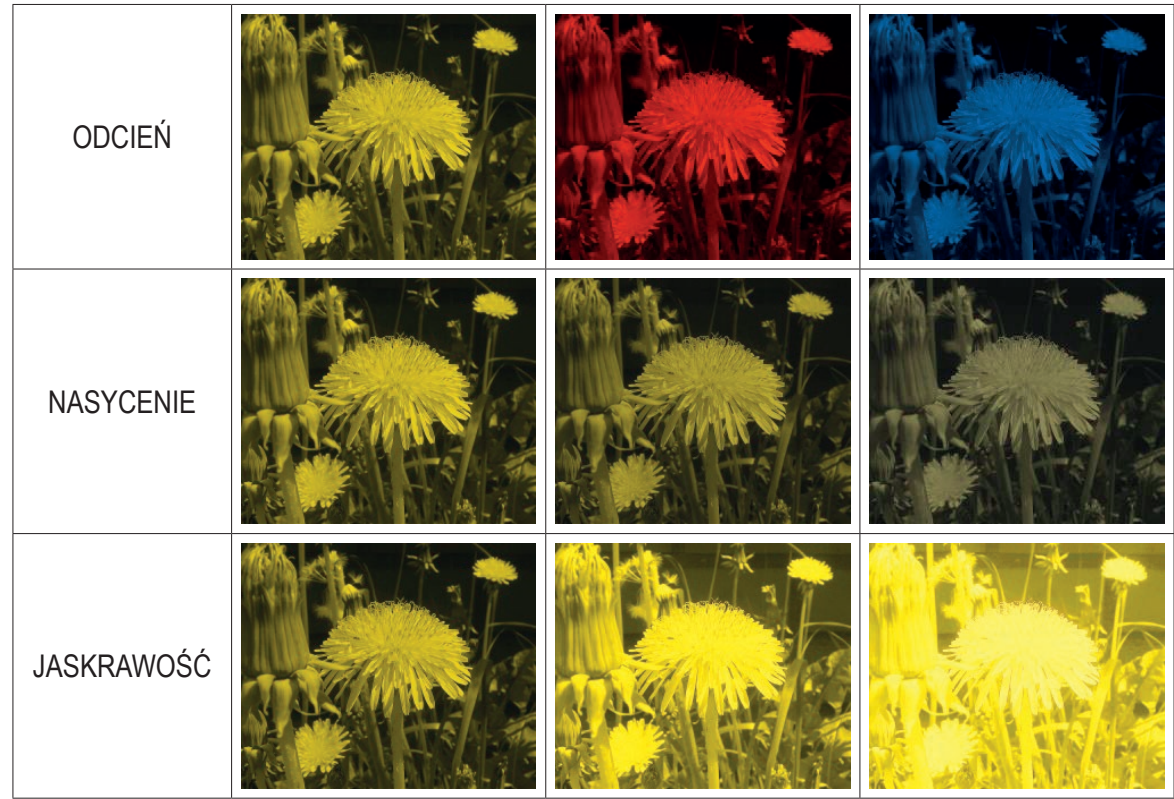

Odcień jest nadrzędnym parametrem, definiującym kolor w sposób ilościowy. Często mylnie jest nazywany po prostu kolorem, być może dlatego, że fizycznie na ogół można go ustalić wyłącznie przy użyciu fal prostych (monochromatycznych), bądź z powodu nieścisłości tłumaczenia dwóch angielskich synonimów: hue, colour. Nasycenie (stosowane są również terminy: intensywność lub saturacja) stanowi zawartość odcienia w określonym kolorze. Zwiększanie ilości światła białego obniża nasycenie, ale percepcja promieniowania pozostaje niezmieniona w odcieniu. Przy dostatecznie dużym udziale światła białego przestajemy postrzegać określony odcień, w efekcie pozostaje jedynie subiektywne wrażenie światła białego. Jaskrawość jest cechą koloru określającą udział poszczególnych barw achromatycznych, czyli bieli, czerni oraz odcieni szarości. Definiuje zmianę koloru, która nie wywołuje zmiany nasycenia. Jaskrawość równa zero to czerń, a jej maksymalna wartość to w pełni nasycony odcień. Opisane parametry stały się podstawą opracowanego w latach 1898-1905 przez amerykańskiego malarza i nauczyciela sztuki Alberta Munsella systemu kolorów (Munsell Color System) (rys. 1). Jego twórca założył, że sąsiadujące kolory muszą różnić się o tę samą wartość i harmonizować ze sobą. Wyznaczył pięć odcieni głównych: 
czerwony $(\mathrm{R})$, żółty $(\mathrm{Y})$, zielony $(\mathrm{G})$, niebieski (B), purpurowy $(\mathrm{P})$ oraz pięć pośrednich: żółtoczerwony (YR), zielonożółty (GY), niebieskozielony (BG), purpurowoniebieski (PB) i czerwonopurpurowy (RP). Ich kombinacje, a także różne stopnie nasycenia (od 0 do 10) i jaskrawości (od 0 do maksymalnie 12) dają skończoną ilość kolorów. Stworzony ponad sto lat temu Munsell Color System był kilkakrotnie udoskonalany. W latach czterdziestych Towarzystwo Optyczne w Ameryce opracowało jego nowoczesną wersję i w tej postaci stał się on podstawą wprowadzonej w 1974 roku Uniform Color Scales. Opisane parametry koloru: odcień, nasycenie i jaskrawość, są również podstawą w badaniach kolorymetrycznych, stanowiących ważną część badań fotostabilności preparatów do scalenia kolorystycznego.

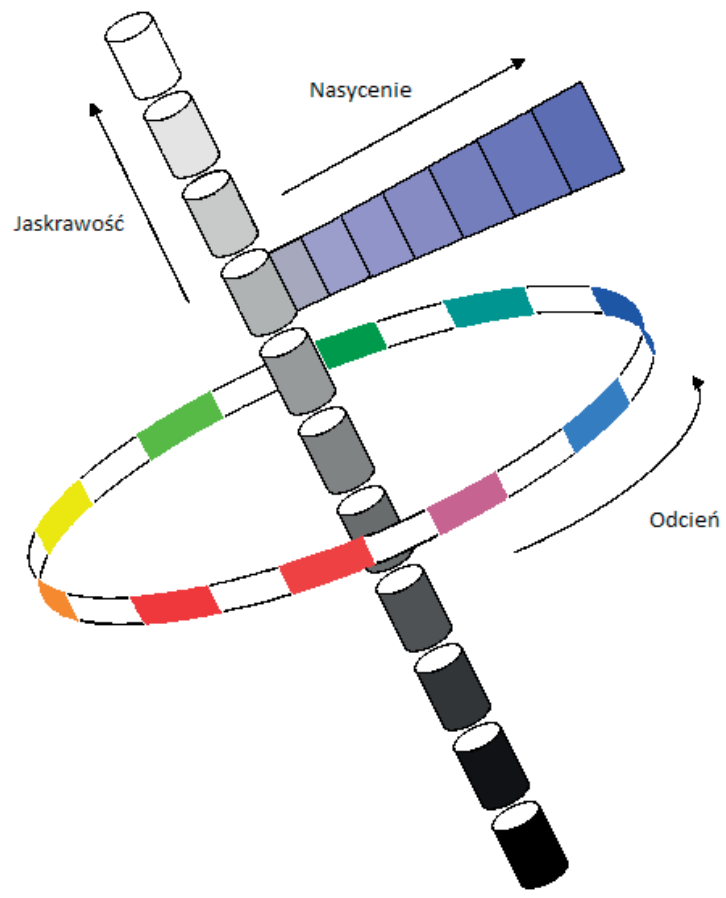

Rys. 1. Munsell Color System. Na podstawie: Janina Gronowska, Podstawy fizykochemii barwników (Toruń: UMK, 1989), 10. Rys. Andrzej Podgórski 


\section{Stabilność barwy spoiw wielkocząsteczkowych}

Pod wpływem promieniowania ultrafioletowego, w obecności tlenu, prawie wszystkie polimery ulegają procesom starzeniowym. Te interakcje prowadzą do nieodwracalnych zmian we właściwościach fizykochemicznych i/lub mechanicznych, co na ogół oznacza pogorszenie się ich właściwości użytkowych. Procesy starzeniowe, w zależności od następstw, mogą być podzielone na dwie grupy: fotodegradację i fotosieciowanie ${ }^{1}$. W efekcie zachodzenia pierwszego procesu następuje rozrywanie łańcucha na krótsze fragmenty, co skutkuje zmniejszeniem masy cząsteczkowej polimeru. Zachowuje on wówczas swoją rozpuszczalność w cieczach, szczególnie o dużej polarności. Natomiast zmianie ulegają takie jego właściwości, jak połysk, kolor (na ogół żółknie) i porowatość. Pogorszają się również jego właściwości mechaniczne w porównaniu do polimeru niezdegradowanego ${ }^{2}$. Pod wpływem procesów fotosieciowania, na skutek powstawania wiązań następuje łączenie się makrocząsteczek w większe, złożone struktury. Polimer, początkowo rozpuszczalny, w wyniku wzrostu masy cząsteczkowej oraz stopnia rozgałęzienia stopniowo traci swoją rozpuszczalność w cieczach. Jej utrata dotyczy wszystkich jego wcześniejszych rozpuszczalników, zarówno polarnych, jak i niepolarnych ${ }^{3}$.

Procesy fotodegradacji i fotosieciowania przebiegają w polimerach jednocześnie. To, na który z nich polimer bardziej jest podatny, zależy od ich wydajności. Proces postępujący w określonych warunkach z większą efektywnością staje się procesem dominującym. Szybkość zachodzenia procesów starzeniowych związków wielkocząsteczkowych jest uzależniona od wielu czynników: ich morfologii, stężenia i szybkości dyfuzji tlenu, oddziaływań międzycząsteczkowych ${ }^{4}$. Przepuszczalność tlenu przez powłoki i/lub spoiny jest określona przez jego rozpuszczalność, uwarunkowaną składem chemicznym

1 Danuta Żuchowska, Polimery konstrukcyjne (Warszawa: WN-T, 2000), 263-268; Wolfram Schnabel, Polymer Degradation Principles and Practical Applications (Berlin: Akademie-Verlag, 1981), 13-23, 95-126.

2 Jerzy Ciabach, Żywice i tworzywa sztuczne stosowane w konserwacji zabytków (Toruń: Wydawnictwo UMK, 1998), 60-71; Schnabel, Polymer, 13-23, 95-126.

3 Ciabach, Żywice, 60-71.

4 Pieter Gijsman, Guido Meijers i Giacomo Vitarelli, “Comparsion of the UV-Degradation Chemistry of Polypropylene, Polyethylene, Polyamide 6 and Polybutyleneterephtalate", Polymer Degradation and Stability 65 (1999): 433-441, DOI:10.1016/S0141-3910(99)00033-6; Edina Epacher et al., "Pocessing Stability of High Density Polyethylene: Effect of Adsorbed and Dissolved Oxygen”, Polymer 41 (2000): 8401-8408, DOI:10.1016/S0032-3861(00)00191-9; Schnabel, Polymer, 13-23, 95-126. 
kompozycji, oraz jego ruchliwością, zależną od morfologii próbki. W polimerach przenikanie odbywa się wzdłuż przestrzeni lub obszarów o mniejszej gęstości (przestrzenie międzycząsteczkowe, obszary amorficzne, powierzchnie modyfikatorów lub/i napełniaczy, ewentualne występujące pory i spękania).

Absorpcja promieniowania przez oparte na związkach wielkocząsteczkowych preparaty stosowane w konserwacji jest związana z przejściem elektronów między odpowiednimi orbitalami ${ }^{5}$. Makrocząsteczki zawierające tylko pojedyncze wiązania typu węgiel-węgiel lub węgiel-wodór, bez żadnych chromoforów ${ }^{6}$ (na przykład polietylen, polipropylen), teoretycznie nie pochłaniają promieniowania o długości fali mniejszej niż $220 \mathrm{~nm}$. Jednak nawet one charakteryzują się pewną absorpcją w tym regionie dzięki obecności zanieczyszczeń i defektów strukturalnych. Popularne polimery zawierające grupy karbonylowe - poli(octan winylu), poli(metakrylan metylu), żywice ketonowe - silnie pochłaniają promieniowanie w zakresie 200-300 nm. Obecność grup chromoforowych, które silnie absorbują promieniowanie ultrafioletowe, jest warunkiem koniecznym do zapoczątkowania wcześniej opisywanych procesów starzeniowych. Zmiana struktury makrocząsteczki, jej składu chemicznego przez wbudowanie w makrołańcuch dodatkowych ugrupowań polarnych, które absorbują promieniowanie o różnych długościach fal, jest przyczyną zmiany długości pochłanianego światła, a w konsekwencji wypadkową obserwowanej barwy kompozycji.

\section{Badania barwnych powłok}

Wygląd zewnętrzny

Badaniom poddano następujące farby ${ }^{7}$ : Restauro Colore a Vernice per Restauro 018 (Miameri Spa, Italy), Restauro Colore a Vernice per Restauro 020

Jest to, upraszczając, rozwiązanie funkcji falowej, której wynik wskazuje na pewne wyróżnione obszary przestrzeni o „rozmytych” granicach, gdzie prawdopodobieństwo wystąpienia elektronu jest duże; Walenty Szczepaniak, Metody instrumentalne $w$ analizie chemicznej (Warszawa: Wydawnictwa Naukowe PWN, 1997), 65-74; Gronowska, Podstawy, 28-41.

6 Jest to indywiduum chemiczne odpowiedzialne za absorpcję promieniowania elektromagnetycznego; Szczepaniak, Metody, 65-74.

7 Według normy branżowej (PN-EN ISO 4618:2014-11) farba jest układem błonotwórczym, podobnie jak lakier, który służy do ochrony i dekoracji powierzchni. Przez pojęcie dekoracji należy tu rozumieć nadanie lub odtworzenie walorów estetycznych powierzchni, natomiast funkcje ochronne to jej zabezpieczenie przed zniszczeniem i/lub pogorszeniem jej odbioru estetycznego. Zasadniczą różnicą między lakierem a farbą jest dodatkowy składnik farb - substancje barwiące. Farby są zatem wyrobami pigmentowanymi, w przeciwieństwie do lakierów. 
(Miameri Spa, Italy), Renesans Colori a Vernice Nr. 1 (Renesans, Polska), Renesans Colori a Vernice Nr. 2 (Renesans, Polska), Van Gogh 104 (Royal Talens, Holland), Louvre 013 (Lefranc \& Bourgeois, France), Decorlack 070 (Marabou GmbH \& Co. KG, Germany), Porcelain 070 (Marabou GmbH \& Co. KG, Germany), GlasArt 470 (Marabou GmbH \& Co. KG, Germany), Gamblin 8081050 (Gamblin Conservation Colors, USA), Kremer 4600090 (Kremer Pigmente GmbH \& Co. KG, Germany), Kremer 4620090 (Kremer Pigmente GmbH \& Co. KG, Germany). Szczegółowy ich skład wymieniono w tabeli 2.

Oceniane pod kątem wyglądu zewnętrznego ${ }^{8}$, wszystkie farby charakteryzują się białym zabarwieniem wynikającym z dodatku odpowiedniego pigmentu (tab. 2). Są to jednorodne układy, bez zanieczyszczeń mechanicznych, o konsystencji pasty, z wyjątkiem produkowanych przez firmę Marabou GmbH \& Co.: Decorlack 070, Porcelain 070, GlasArt 470, które mogą stanowić gotowy produkt, przeznaczony do bezpośredniego użycia (bez konieczności ich rozcieńczania). Pozostałe, w celu ułatwienia aplikacji pędzlem na wybrane podłoże i uzyskania jak najgładszej powierzchni, warto rozcieńczyć dodając odpowiedni rozcieńczalnik: mieszaninę metoksypropanolu z metoksydipropanolem, benzynę lakową, octan etylu, terpentynę, wodę i inne9. Sterując ich ilością uzyskuje się także zróżnicowanie powłok pod względem ich siły krycia. Oznaczony stopień połysku (tab. 2), podobnie jak konsysten-

Znaczna część farb w swoim składzie zawiera również inne dodatki w postaci wypełniaczy, rozcieńczalników, stabilizatorów, substancji konserwujących itd. Termin „farba” według podanej definicji może być, z bardzo dużym uproszczeniem, zamiennie stosowany:

a) z określeniem „barwna kompozycja” - co oznaczałoby tu zestawienie poszczególnych składowych układu błonotwórczego ze sobą w taki sposób, by tworzyły one spójną całość (o określonej barwie, połysku, właściwościach mechanicznych itd.);

b) z określeniem „kompozyt polimerowy” - co oznaczałoby materiał utworzony z co najmniej dwóch komponentów (faz) o różnych właściwościach w taki sposób, że uzyskiwane są właściwości lepsze i/lub zmodyfikowane w stosunku do komponentów analizowanych osobno albo wynikających z prostego sumowania ich właściwości. W farbie jedną z faz stanowi spoiwo wielkocząsteczkowe, drugą zaś cząstki pigmentu. Zmieszane ze sobą zyskują zdolność do tworzenia ciągłych struktur o określonych właściwościach mechanicznych i zabarwieniu - osobno nie mają takiej możliwości.

8 Ocenę wyglądu zewnętrznego wykonano zgodnie z normą PN-EN ISO 2813:2001. Zestalone powłoki na płytkach szklanych $(100 \times 100 \mathrm{~mm})$ obserwowano okiem nieuzbrojonym, uwzględniając: połysk, transparentność, obecność zanieczyszczeń, zmarszczek, śladów duktu pędzla.

9 Elżbieta Szmit-Naud, „Uzupełnienia ubytków warstwy malarskiej obrazów: badania materiałów stosowanych współcześnie”, Acta Universitatis Nicolai Copernici, Zabytkoznawstwo i Konserwatorstwo 34 (2005): 65-102; Elżbieta Szmit-Naud, „Farby dla konserwatorów malarstwa - właściwości aplikacyjne i stabilność”, Ochrona Zabytków 60 (2007): 59-68. 
Tabela 2. Skład badanych preparatów powłokotwórczych oraz wyznaczony stopień połysku uzyskanych z nich powłok

\begin{tabular}{|c|c|c|c|}
\hline Farba & Spoiwo & Pigment & $\begin{array}{l}\text { Stopień } \\
\text { połysku }\end{array}$ \\
\hline $\begin{array}{l}\text { Restauro Colore } \\
\text { a Vernice per Restauro } 018\end{array}$ & mastyksowe & $\begin{array}{l}\text { biel tytanowa (PW6/ } \\
\text { PW4)* }\end{array}$ & półmat \\
\hline $\begin{array}{l}\text { Restauro Colore } \\
\text { a Vernice per Restauro } 020\end{array}$ & mastyksowe & biel cynkowa (PW4) & półmat \\
\hline Renesans Colori a Vernice Nr. 1 & ketonowe & biel tytanowa (PW6) & półmat \\
\hline Renesans Colori a Vernice Nr. 2 & ketonowe & biel cynkowa (PW4) & półmat \\
\hline Talens Van Gogh 104 & szybkoschnący olej & biel cynkowa (PW4) & półmat \\
\hline Louvre 013 & szybkoschnący olej & $\begin{array}{l}\text { bieli tytanowa z bielą } \\
\text { cynkową (PW6/PW4) }\end{array}$ & półmat \\
\hline Decorlack 070 & akrylowe & biel tytanowa* & połysk \\
\hline Porcelain 070 & akrylowe ${ }^{* *}$ & biel tytanowa* & połysk \\
\hline GlasArt 470 & alkidowe $^{* *}$ & biel tytanowa* & połysk \\
\hline Gamblin 8081050 & mocznikowo-aldehydowe & biel tytanowa (PW6) & półmat \\
\hline Kremer 4600090 & akrylowe & biel ołowiana & półmat \\
\hline Kremer 4620090 & akrylowe & biel tytanowa & półmat \\
\hline
\end{tabular}

* Oznaczenie pigmentu wykonano analizatorem XRF serii Delta model DS-2000, Innov-X System, w trybie analizy stopów - Alloy Plus.

** Producent nie podaje informacji na temat spoiwa zawartego w farbie. Rodzaj spoiwa ustalono na podstawie analizy FTIR model Alpha-P, Bruker. 
cja, odróżnia produkty firmy Marabou $\mathrm{GmbH} \&$ Co. od pozostałych analizowanych farb. Mierzony połysk nie odgrywa aż tak istotnej roli, gdyż barwna warstwa nie musi stanowić finalnego wykończenia. Użycie odpowiedniego lakieru i/lub czynnika matującego jest w stanie nadać powierzchni odpowiedni stopień połysku.

Twardość względna, elastyczność

Warstwa emalierska jako powłoka dekoracyjno-ochronna odznacza się wyjątkową twardością i kruchością. Pojawiające się na zabytkowym obiekcie zniszczenia warstwy szkliwa wywołane przez czynniki mechaniczne (naprężenia powstałe w trakcie wytwarzania przedmiotu, pochodne jego konstrukcji, przypadkowe uderzenie, użytkowanie, zmiana funkcji) uzależnione są od siły działającej na obiekt, od geometrii obiektu, stanu zachowania oraz składu emalii i zastosowanej techniki emalierskiej. Powodują one zmniejszenie przyczepności warstwy dekoracyjnej do podłoża, spękania, rozwarstwienia, a w skrajnych przypadkach jej odspojenie od podłoża, dlatego istotnym parametrem, decydującym o możliwości zastosowania analizowanych farb, są ich właściwości mechaniczne. Wytworzona na bazie badanych barwnych kompozycji powłoka powinna mieć właściwości mechaniczne zbliżone do scalanej kolorystycznie emalii. Jest nawet wskazane, by cechowała się nieco gorszymi parametrami od oryginału, co zapewni w pierwszej kolejności zniszczenie wtórnej materii zabytkowej z zachowaniem warstwy oryginalnej. Wtedy stanowić będzie swoisty indykator reagujący na niepożądane zmiany, jakie zachodzą na obiekcie.

Najtwardsze ${ }^{10}$ powłoki wytworzyły kompozycje oparte na spoiwie mastyksowym (Miameri Spa) oraz na bazie Paraloidu B-72 (Kremer Pigmente $\mathrm{GmbH} \& \mathrm{Co}$.). W przeciwieństwie do nich, najniższe wartości oznaczanego parametru (tab. 3) wykazały barwne kompozycje olejne (Talens, Lefranc \& Bourgeois), a także farby Marabou GmbH \& Co. - Porcelain 070 oraz GlasArt 470. O ile w przypadku farb mastyksowych, których spoiwo cechuje się dużą kruchością i łupliwością, oraz farb olejnych, charakteryzujących się miękkością i elastycznością, można było prognozować wielkość badanego para-

10 Pomiar twardości względnej wykonano zgodnie z normą PN-EN ISO 1522:2008. Powłoki naniesiono na płytki szklane o wymiarach 100 x 100 x 5 [mm]. Badanie wykonano aparatem pomiarowym za pomocą wahadła Königa. Przeprowadzono serię trzech oznaczeń na wzorcowej płytce szklanej w różnych miejscach. Twardość względną powłoki $\left(\mathrm{T}_{\mathrm{wz}}\right)$ obliczono ze stosunku liczby wahnięć na płytce pokrytej farbą do liczby wahnięć na płytce wzorcowej (szklanej). Przeprowadzono serię pięciu oznaczeń, z których wyznaczono średnią arytmetyczną. 
Tabela 3. Twardość względna oraz elastyczność barwnych kompozycji proponowanych do scalenia kolorystycznego warstwy emalierskiej

\begin{tabular}{|c|c|c|}
\hline Farba & $\begin{array}{l}\text { Twardość } \\
\text { względna }\end{array}$ & Elastyczność \\
\hline $\begin{array}{l}\text { Restauro Colore a Vernice per Restauro } \\
018\end{array}$ & 0,43 & $\begin{array}{l}\text { ф20 siatka spękań, } \\
\text { odspojenie powłoki od podłoża }\end{array}$ \\
\hline $\begin{array}{l}\text { Restauro Colore a Vernice per Restauro } \\
020\end{array}$ & 0,40 & $\begin{array}{l}\text { ф } 20 \text { siatka spękań, } \\
\text { odspojenie powłoki od podłoża }\end{array}$ \\
\hline Renesans Colori a Vernice Nr. 1 & 0,22 & $\begin{array}{l}\text { ф10 siatka spękań, } \\
\text { odspojenie powłoki od podłoża }\end{array}$ \\
\hline Renesans Colori a Vernice Nr. 2 & 0,24 & $\begin{array}{l}\text { ф10 siatka spękań, } \\
\text { odspojenie powłoki od podłoża }\end{array}$ \\
\hline Van Gogh 104 & 0,06 & brak zmian \\
\hline Louvre 013 & 0,06 & brak zmian \\
\hline Decorlack 070 & 0,30 & brak zmian \\
\hline Porcelain 070 & 0,08 & brak zmian \\
\hline GlasArt 470 & 0,11 & brak zmian \\
\hline Gamblin 8081050 & 0,33 & $\begin{array}{l}\text { ф } 3 \text { drobne spękania, częściowe } \\
\text { odspojenie powłoki od podłoża }\end{array}$ \\
\hline Kremer 4600090 & 0,44 & brak zmian \\
\hline Kremer 4620090 & 0,40 & brak zmian \\
\hline
\end{tabular}

metru, o tyle uzyskany wynik Porcelain 070 wskazuje na zastosowanie jako spoiwa polimeru o stosunkowo niskiej temperaturze zeszklenia i/lub małej masie cząsteczkowej ${ }^{11}$. Natomiast przyczyną tak małej twardości względnej

11 Temperatura zeszklenia jest jednym z parametrów charakteryzujących spoiwo wielkocząsteczkowe pod względem jego podatności na odkształcenie. Im niższa temperatura zeszklenia, tym spoiwo bardziej jest podatne na odkształcenie. Temperatura zeszklenia jest uzależniona od masy cząsteczkowej spoiwa - rośnie do charakterystycznej wielkości wraz ze wzrostem jego masy cząsteczkowej. 
GlasArt 470 jest dodatek modyfikatora właściwości mechanicznych. W farbach alkidowych właściwości mechaniczne są kontrolowane ilością i typem oleju dodanego podczas ich syntezy.

Nie odnotowano istotnego wpływu użytego rodzaju pigmentu (bieli) na twardość barwnej powłoki w obrębie jednego spoiwa i producenta.

Podczas testów elastyczności ${ }^{12}$ powłoki farb opartych na spoiwach mastyksowych, mocznikowo-aldehydowych i ketonowych uległy zniszczeniom (tab. 3). Zaobserwowano pękanie połączone z całkowitym lub fragmentarycznym odspojeniem od podłoża. Struktury cykliczne decydują o bardzo dobrym współczynniku załamania światła, ale niestety są też odpowiedzialne za dużą kruchość (spoiwa mastyksowe, ketonowe) ${ }^{13}$. W żywicach mocznikowo-formaldehydowych między makrocząsteczkami występują silne oddziaływania natury polarnej i wiązań wodorowych, które „usztywniają” całą strukturę ${ }^{14}$.

Największą elastycznością wśród badanych powłok odznaczały się błony uzyskane ze spoiw olejnych, alkidowych i akrylowych (w tym też oparte na Paraloidzie B-72). Jest to uwarunkowane strukturą związków wielkocząsteczkowych. Oleje szybkoschnące po zestaleniu charakteryzują się relatywnie niewielką gęstością usieciowania, co ułatwia wzajemne przemieszczanie się makrocząsteczek względem siebie i zapewnia podatność na odkształcenie ${ }^{15}$. Natomiast elastyczność kopolimeru (Paraloid B-72), jego skład oraz niewielki stopień polimeryzacji warunkują niską temperaturę zeszklenia, czyli dużą podatność na odkształcenie ${ }^{16}$.

Na podstawie uzyskanych wyników można stwierdzić, że nie ma prostej zależności między twardością względną a elastycznością. Powłokę może cechować duża twardość, ale -przykładem farba produkowana przez Kremer Pigmente GmbH \& Co. - zachowuje ona dużą elastyczność.

Mając na uwadze wyniki uzyskane podczas przedstawionych oznaczeń, przydatność badanych preparatów jako materiałów do unifikacji kolorystycznej zniszczonej warstwy emalierskiej należy uszeregować w następującej

12 Pomiar elastyczności wykonano zgodnie z normą PN-EN ISO 1519:2002. Mosiężne płytki o wymiarach $25 \times 150$ x 0,2 [mm] pokryte jednostronnie preparatami zginano na sworzniach o zmniejszającej się średnicy (20, 16, 12, 8, 4, 2 mm). Jako wynik przyjęto średnicę sworznia, przy którym powłoka uległa zniszczeniu.

13 Ciabach, Żywice, 213-217; Szmit-Naud, „Uzupełnienia”, 65-102; Szmit-Naud, „Farby”, 59-68.

14 Ciabach, Żywice, 193-196.

15 Iłłarion S. Ochrimenko i Władimir W. Wierchołancew, Chemia i technologia substancji błonotwórczych, tłum. J. Urbański (Warszawa: WN-T, 1982), 298-334.

16 Ciabach, Żywice, 121-123. 
kolejności: Najlepszy wybór stanowi Gamblin 8081050 - cechuje go duża twardość, ale ograniczona elastyczność. Decorlack 070, Kremer 4620090 oraz Kremer 4620090 to farby możliwe do zastosowania, wykonania retuszu, z zastrzeżeniem ustabilizowania obiektu wobec niszczących czynników mechanicznych. Do trzeciej grupy należy zaliczyć pozostałe kompozycje (Restauro 018, Restauro 020, Renesans Nr. 1, Renesans Nr. 2, Van Gogh 104, Louvre 013, Porcelain 070, GlasArt 470), których użycie będzie związane bądź to z okresowym, częstym powtarzaniem zabiegu unifikacji kolorystycznej w wyniku zniszczenia i odspojenia barwnych powłok od podłoża, bądź uszkodzeniami w pierwszej kolejności warstw oryginalnych w wyniku działania w obiekcie naprężeń wynikających ze zbyt dużej elastyczności i podatności na odkształcenie wtórnej materii w porównaniu do oryginału. Poza tym im warstwa jest grubsza, tym większe zachodzi prawdopodobieństwo występowania niedoskonałości struktury w postaci spękań lub szczelin, czyli powłoka wykazuje mniejszą kohezję ${ }^{17} \mathrm{i}$ jest bardziej podatna na uszkodzenie.

\section{Adhezja}

Istotnym parametrem przy doborze farby do scalenia kolorystycznego jest przyczepność powłoki do podłoża - zarówno do emalii, jak i do kompozytu ${ }^{18}$, który służy do uzupełniania ubytku.

Badanie przyczepności powłok wykonano metodą odrywową automatycznym testerem PosiTest Model AT-A. Przyrząd dokonuje pomiaru siły potrzebnej do oderwania od badanej powłoki przytwierdzonego do niej tłoczka ${ }^{19}$. Przekrój analizowanego układu (rys. 2) może być bardzo pomocny przy zrozumieniu dwutorowości pomiarów adhezji do różnych rodzajów podłoży. Farbę nakładano na szklane podłoże, które może stanowić odpowiednik war-

17 Jan F. Rabek, Polimery. Otrzymywanie, metody badawcze, zastosowanie (Warszawa: Wydawnictwo Naukowe PWN, 2013), 308-344.

18 Arletta Piasecka, Andrzej Podgórski, Alina Tomaszewska-Szewczyk, „Metody imitatorskie uzupełniania dekoracji emalierskiej: zastosowanie kompozytów polimerowych na bazie żywic epoksydowych", Acta Universitatis Nicolai Copernici, Zabytkoznawstwo i Konserwatorstwo 47 (2016): 273-298, http://dx.doi.org/10.12775/AUNC_ZiK.2016.010.

19 Pomiar adhezji wykonano zgodnie z normą PN-EN ISO 4624:2004. W badaniach posłużono się automatycznym testerem przyczepności powłok PosiTest AT-A wyposażonym w sterowaną elektronicznie pompę hydrauliczną. Uzyskane spoiny łączono z tłoczkiem żywicą epoksydową Loctite 3423 (spoiwo + utwardzacz). Czas utwardzania wynosił 72 godziny, temperatura pokojowa pod ciśnieniem atmosferycznym. Cienką warstwę farby naniesiono na płytki szklane (odpowiednik warstwy emalierskiej) o wymiarach $100 \times 100 \times 5$ [mm], a następnie wykonano próbę odrywu przytwierdzonego do nich tłoczka o średnicy $20[\mathrm{~mm}]$ z prędkością 0,20 $[\mathrm{MPa} / \mathrm{s}]$. Przeprowadzono serię pięciu oznaczeń, z których wyznaczono średnią arytmetyczną. 
stwy emalierskiej ze względu na zbliżoną naturę i rodzaj oddziaływań szkła oraz emalii. Między barwną powłoką a tłoczkiem znajdował się klej na bazie żywicy epoksydowej - odpowiednik masy do uzupełnień ubytków.
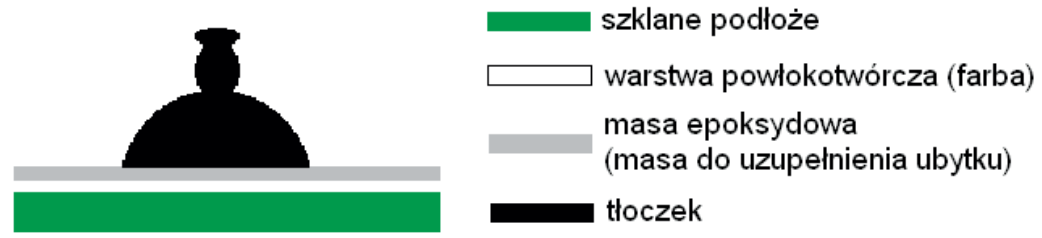

Rys. 2. Schemat przekroju poprzecznego układu do badania przyczepności farb. Rys. Andrzej Podgórski

Różnice w sile odrywu (F) (tab. 4) wynikają bądź z różnic w budowie chemicznej samego spoiwa lub/i zastosowanych dodatków do kompozycji, bądź/i z różnic zwilżalności podłoża przez same preparaty (farba do powierzchni szklanej, farba do żywicy epoksydowej). Największą siłę odrywu wśród badanych farb (tab. 4) odnotowano dla powłok uzyskanych z preparatów Decorlack 070 i Porcelain 070. Ze względu na zbyt dużą adhezję do szklanego podłoża oraz do żywicy epoksydowej (około 7,0 MPa) wyeliminowano je z dalszych rozważań nad materiałami nadającymi się do scalenia kolorystycznego. Ich użycie może w przyszłości skutkować zniszczeniem osłabionej substancji zabytkowej.

Najmniejszą siłą odrywu (tab. 4) cechowały się farby Renesans Colori a Vernice (około 1,5 MPa). Niestety siły spójności w obrębie warstwy - co szczególnie dotyczy Renesans Colori a Vernice Nr. 2, w której skład wchodzi biel cynkowa - są niewielkie i dochodzi do zerwania kohezyjnego ${ }^{20}$. Może to być spowodowane źle dobranym stosunkiem spoiwa do pigmentu lub słabą zwilżalnością, niewystarczającym otoczeniem cząstek pigmentu przez żywicę, co może skutkować dezintegracją granularną (pudrowaniem się) pigmentu. Spostrzeżenia dotyczące farb opartych na spoiwach ketonowych odnoszą się również do kompozycji bazujących na spoiwie olejnym, z tą różnicą, że ich powłoki mają większą siłę odrywu.

20 Rabek, Polimery, 349-364. 
Tabela 4. Przyczepność barwnych kompozycji proponowanych do scalenia kolorystycznego warstwy emalierskiej

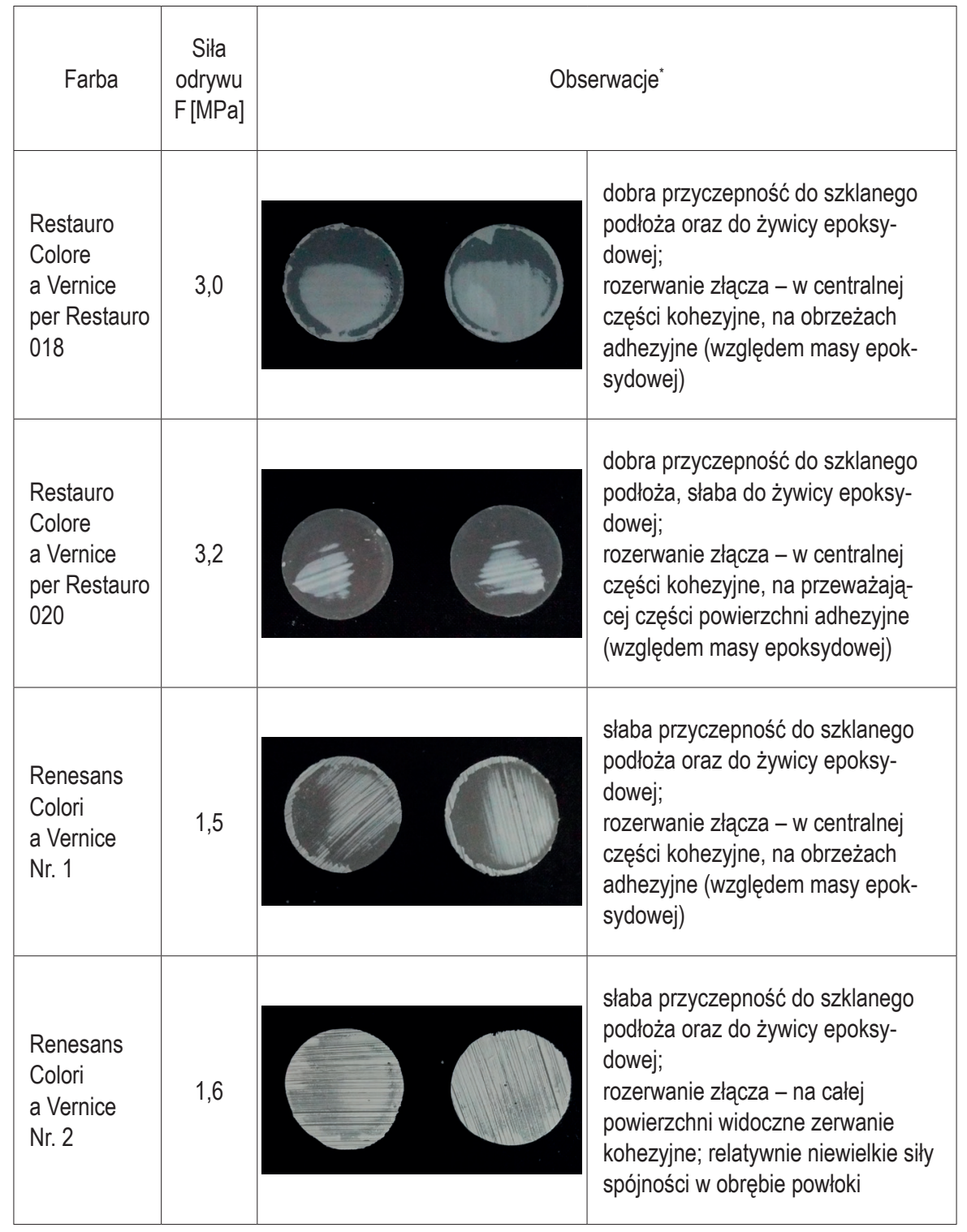

* Jan F. Rabek, Polimery. Otrzymywanie, metody badawcze, zastosowanie (Warszawa: Wydawnictwo Naukowe PWN, 2013), 349-364. 
Cd. tab. 4

\begin{tabular}{|c|c|c|}
\hline $\begin{array}{l}\text { Van Gogh } \\
104\end{array}$ & 3,5 & $\begin{array}{l}\text { dobra przyczepność do szklanego } \\
\text { podłoża oraz do żywicy epoksy- } \\
\text { dowej; } \\
\text { rozerwanie złącza - na całej } \\
\text { powierzchni widoczne zerwanie } \\
\text { kohezyjne; relatywnie niewielkie sily } \\
\text { spójności w obrębie powłoki }\end{array}$ \\
\hline $\begin{array}{l}\text { Louvre } \\
013\end{array}$ & 2,3 & $\begin{array}{l}\text { dobra przyczepność do szklanego } \\
\text { podłoża oraz do żywicy epoksy- } \\
\text { dowej; } \\
\text { rozerwanie złaczza - na całej po- } \\
\text { wierzchni dominuje zerwanie kohe- } \\
\text { zyjne; małe siły spójności } \\
\text { w obrębie powłoki }\end{array}$ \\
\hline $\begin{array}{l}\text { Decorlack } \\
070\end{array}$ & 7,2 & $\begin{array}{l}\text { bardzo dobra przyczepność do } \\
\text { szklanego podłoża oraz do żywicy } \\
\text { epoksydowej; } \\
\text { nie odnotowano zerwania złącza }\end{array}$ \\
\hline $\begin{array}{l}\text { Porcelain } \\
070\end{array}$ & 7,1 & $\begin{array}{l}\text { bardzo dobra przyczepność do } \\
\text { szklanego podłoża, niewiele gorsza } \\
\text { do żywicy epoksydowej; } \\
\text { rozerwanie złacza - adhezyjne } \\
\text { (względem masy epoksydowej) }\end{array}$ \\
\hline $\begin{array}{l}\text { GlasArt } \\
470\end{array}$ & 2,9 & $\begin{array}{l}\text { słaba przyczepność do szklanego } \\
\text { podłoża, dobra do żywicy epoksy- } \\
\text { dowej; } \\
\text { rozerwanie złacza - w centralnej } \\
\text { czesści adhezyjne (względem } \\
\text { szklanego podłoża), na obrzeżach } \\
\text { adhezyjne (względem masy epok- } \\
\text { sydowej) }\end{array}$ \\
\hline
\end{tabular}


Cd. tab. 4

\begin{tabular}{|c|c|c|}
\hline $\begin{array}{l}\text { Gamblin } \\
8081050\end{array}$ & 2,1 & $\begin{array}{l}\text { słaba przyczepność do szklanego } \\
\text { podłoża, dobra do żywicy epoksy- } \\
\text { dowej; } \\
\text { rozerwanie złącza - w centralnej } \\
\text { części adhezyjne (względem } \\
\text { szklanego podłoża), na obrzeżach } \\
\text { adhezyjne (względem masy epok- } \\
\text { sydowej) }\end{array}$ \\
\hline $\begin{array}{l}\text { Kremer } \\
4600090\end{array}$ & 5,3 & $\begin{array}{l}\text { słaba przyczepność do szklanego } \\
\text { podłoża, dobra do żywicy epoksy- } \\
\text { dowej; } \\
\text { rozerwanie złącza - w przeważa- } \\
\text { jącej części adhezyjne (względem } \\
\text { szklanego podłoża), adhezyjne } \\
\text { (względem masy epoksydowej) }\end{array}$ \\
\hline $\begin{array}{l}\text { Kremer } \\
4620090\end{array}$ & 5,6 & $\begin{array}{l}\text { słaba przyczepność do szklanego } \\
\text { podłoża, dobra do żywicy epoksy- } \\
\text { dowej; } \\
\text { rozerwanie złącza - w przeważa- } \\
\text { jącej części adhezyjne (względem } \\
\text { szklanego podłoża), adhezyjne } \\
\text { (względem masy epoksydowej) }\end{array}$ \\
\hline
\end{tabular}

Badane produkty firm Gamblin Conservation Colors, Kemer Pigmente $\mathrm{GmbH} \&$ Co. oraz Miameri Spa wykazują nieznacznie lepszą przyczepność do żywicy epoksydowej niż do podłoża szklanego. Na podstawie miary adhezji oraz obserwacji podczas eksperymentu można stwierdzić, że mogą być użyte do odtworzenia opracowań malarskich bezpośrednio na kompozycie stosowanym do uzupełnienia ubytku, jak również na emalii. Ograniczona przyczepność do warstwy dekoracyjnej byłaby niewątpliwie zaletą.

Wyniki doświadczenia pokazują (tab. 4) ograniczenia badanych produktów. Nie nadają się one do tworzenia ciągłych, cienkich filmów polimerowych nawet na niewielkich powierzchniach z zachowaniem dostatecznej adhezji do podłoża i kohezji w obrębie powłoki. Trudno jest z nich uzyskać ciągły twór na dużej powierzchni, o zbliżonych parametrach mechanicznych. Farby mogą jednak być z powodzeniem stosowane do punktowania. 
Na podstawie przeprowadzonych badań nie można również stwierdzić, w jaki sposób dodatek różnych rodzajów pigmentów do tego samego gatunku spoiwa wpływa w ujęciu jakościowym i/lub ilościowym na miarę adhezji wytworzonych w ten sposób barwnych powłok. Wprawdzie pojawiają się różnice w mierzonej przyczepności, lecz porównanie przyczepności powłok bez pewności co do identycznego stężenia pigmentu w spoiwach, identycznego rozmiaru cząstek różnych gatunków bieli, identycznej zwilżalności pigmentów przez spoiwo bądź grubości uzyskanych powłok jest bezcelowe.

Odporność na ścieranie erozyjne

Zjawiska erozyjne dotyczą każdego rodzaju materiału, nie tylko skalnego ${ }^{21}$. W procesie tym obserwuje się ubytek masy wskutek oddziaływań sił dynamicznych, odkształcenia plastyczne i zmęczenie materiału w jego strefie przypowierzchniowej. Odporność materiałów powłokotwórczych na ścieranie jest zatem uwarunkowana właściwościami uzyskanej warstwy, tzn. jej składem (rodzaj spoiwa, zawartość ewentualnych dodatków), jej właściwościami mechanicznymi (podatność na odkształcenie), ale także warunkami, w jakich aplikowano farbę oraz panującymi podczas zestalenia i sezonowania, a ponadto parametrami badawczymi ${ }^{22}$.

Wyznaczona w eksperymencie wartość odporności na ścieranie jest miarą wytrzymałości powłoki po zestaleniu na zużycie w wyniku tarcia, takiego jak wielokrotne przetarcie miękkim materiałem na przykład w czasie czyszczenia lub odpylenia. Nie jest ona i nie powinna być utożsamiana z możliwością obróbki mechanicznej powłoki malarskiej (jej zmatowienia bądź nadania powierzchni zamierzonej faktury), albowiem uzyskanie odpowiednio grubych tworów (wielowarstwowych) nie spowoduje jej usunięcia z podłoża.

Badanie odporności na ścieranie abrazyjne materiału sprowadza się do jego zniszczenia w wyniku mechanicznego oddziaływania cząstek ciał sta-

21 Nektaria Barkoula i Jozsef Karger-Kocsis, "Review Processes and Influencing Parameters of the Solid Particle Erosion of Polymers and Their Composites”, Journal of Materials Science 37, no. 18 (2002): 3807-3820, DOI: $10.1023 /$ A:1019633515481.

22 Danuta Kotnarowska, "Effect of Nanofillers on Wear Resistance of Polymer Coatings", Solid State Phenomena 144 (2009): 285-290, DOI: 10.4028/www.scientific.net/SSP.144.285; Gaurav Gupta i Alok Sata, "Processing, Characterization, and Erosion Wear Characteristics of Borosilicate Glass Microspheres Filled Epoxy Composites”, Polymer Composites 36, no. 9 (2015): 1685-1692, DOI 10.1002/pc.23079; Aseel Basim et al., „Erosion Wear Behavior of Micro Material Reinforced Polymer Composites”, International Journal of Scientific \& Engineering Research 7, no. 2 (2016): 972-984, www.ijser.org/researchpaper/Erosion-Wear-behavior-of-Micro-material-Reinforced-polymer-composites.pdf, Dostęp 20 lutego 2017. 
Tabela 5. Odporność na ścieranie barwnych kompozycji proponowanych do scalenia kolorystycznego warstwy emalierskiej

\begin{tabular}{|l|c|c|c|}
\hline \multicolumn{1}{|c|}{ Farba } & $\begin{array}{c}\text { Grubość } \\
\text { powłoki } \\
{[\mu \mathrm{m}]}\end{array}$ & $\begin{array}{c}\text { Masa } \\
\text { ścierniwa } \\
{[\mathrm{kg}]}\end{array}$ & $\begin{array}{c}\text { Średnia } \\
\text { odporność } \\
\text { na ścieranie } \\
{[\mathrm{kg} / \mu \mathrm{m}]}\end{array}$ \\
\hline Restauro Colore a Vernice per Restauro 018 & $42 \div 54$ & $1,3 \div 1,8$ & 0,03 \\
\hline Restauro Colore a Vernice per Restauro 020 & $48 \div 65$ & $3,8 \div 4,9$ & 0,08 \\
\hline Renesans Colori a Vernice Nr. 1 & $41 \div 53$ & $0,6 \div 0,8$ & 0,01 \\
\hline Renesans Colori a Vernice Nr. 2 & $38 \div 44$ & $0,3 \div 0,4$ & 0,01 \\
\hline Van Gogh 104 & $29 \div 34$ & $1 \div 1,1$ & 0,03 \\
\hline Louvre 013 & $33 \div 45$ & $1,1 \div 1,6$ & 0,03 \\
\hline Decorlack 070 & $36 \div 41$ & $2,7 \div 3,1$ & 0,07 \\
\hline Porcelain 070 & $32 \div 43$ & $4,3 \div 5,4$ & 0,13 \\
\hline GlasArt 470 & $64 \div 68$ & $6,3 \div 6,4$ & 0,11 \\
\hline Gamblin 8081050 & $29 \div 38$ & $0,7 \div 0,9$ & 0,02 \\
\hline Kremer 4600090 & $41 \div 43$ & 0,5 & 0,01 \\
\hline Kremer 4620090 & $35 \div 1,0$ & 0,02 \\
\hline
\end{tabular}

łych o dużej energii kinetycznej. Do oceny odporności na ścieranie abrazyjne barwnych powłok przyjęto wartość stosunku $(S)$ całkowitej masy elektrokorundu $(m)$ powodującej przetarcie powłoki wraz z odsłonięciem podłoża do grubości tej powłoki ${ }^{23}(a)$ liczoną według wzoru:

$$
S=\frac{m}{a}[\mathrm{~kg} / \mu \mathrm{m}]
$$

23 Grubość powłoki zmierzono miernikiem PosiTector 200 B/Std, DeFelsko, USA. 
W przeprowadzonym eksperymencie potwierdzono korelacje między elastycznością powłok a ich odpornością na ścieranie (tab. 5). Powłoki farb bazujących na spoiwach olejnych i akrylowych, które cechowały się dużą elastycznością, podatnością na odkształcenie, wykazują największą odporność na ścieranie (co najmniej $0,02 \mathrm{~kg} / \mu \mathrm{m}$ ). Natomiast farby, które ulegały zniszczeniu w badaniach elastyczności, są na ogół podatne na ścieranie (około $0,01 \mathrm{~kg} / \mu \mathrm{m})$. Wyjątek stanowią kompozycje produkowane przez Miameri Spa. Ich tak duża odporność na ścieranie może wynikać ze składu kompozycji albo - co jest bardziej prawdopodobne - należy ją przypisać pozostałości rozcieńczalnika. Do rozcieńczenia farb Restauro Colore a Vernice per Restauro użyto terpentyny. Istnieje możliwość okludowania jej w mastyksie, zwłaszcza w błonach o znacznej grubości (tab. 5). Pozostałości rozcieńczalnika w powłoce działają jak plastyfikator, zwiększając ilość ścierniwa niezbędnego do odsłonięcia podłoża.

\section{Stabilność powłok na promieniowanie ultrafioletowe}

Oznaczenie stabilności koloru kompozycji na działanie promieniowania ultrafioletowego ${ }^{24}$ wykonano metodą odbiciową przy użyciu spektrofotometru MiniScan XE Plus firmy HunterLab The Color Managment Company. Oznaczono stopień zmiany koloru próbek $\left(\Delta \mathrm{E}^{*}\right)$ na podstawie pomiarów dokonanych przed i po ekspozycji na to promieniowanie. Stopień zmiany zawarty w przedziale $0-2$ jest praktycznie nierozpoznawalny dla obserwatora; wartość w granicach 2-3 jest zauważalna tylko dla wprawnego oka, a powyżej 3 różnica barwy jest wyraźnie odbierana.

Zmiany koloru wywołane promieniowaniem ultrafioletowym odnotowano w każdej analizowanej próbce. Wyniki uzyskane eksperymentalnie zamieszczono w tabeli 6 . Uchwycone różnice $\Delta \mathrm{E}^{*}$ między wyrobami poszczególnych producentów farb wynikają z różnic w budowie chemicznej spoiwa wielkocząsteczkowego użytego do sporządzenia handlowych preparatów. Powodować je mogą również dodatki w postaci plastyfikatorów lub stabilizatorów, które zawiera barwna kompozycja, jak również natura chemiczna użytego pigmentu w obrębie tego samego spoiwa.

24 Próbki farb naniesione na szklane płytki o wymiarach 50 x 50 mm naświetlano w temperaturze pokojowej w atmosferze powietrza pod niskociśnieniową lampą rtęciową TUV - 30W, Philips $(\lambda=254 \mathrm{~nm}$ ). Odległość między źródłem promieniowania a próbkami wynosiła $5 \mathrm{~cm}$; natężenie promieniowania, zmierzone przy użyciu miernika promieniowania IL 1400A International Light, wynosiło $16,67 \mathrm{~W} / \mathrm{m}^{2}$. Próbki poddano dawce promieniowania padającego wynoszącej w przybliżeniu $4500 \mathrm{~kJ} / \mathrm{m}^{2}$, w interwałach co $900 \mathrm{~kJ} / \mathrm{m}^{2}$. 
Tabela 6. Zmiana koloru kompozycji proponowanych do scalenia kolorystycznego warstwy emalierskiej

\begin{tabular}{|l|c|c|c|c|c|}
\hline \multicolumn{1}{|c|}{ Farba } & $\begin{array}{c}\Delta \mathrm{E}^{*} \\
\left(900 \mathrm{~kJ} / \mathrm{m}^{2}\right)\end{array}$ & $\begin{array}{c}\Delta \mathrm{E}^{*} \\
\left(1800 \mathrm{~kJ} / \mathrm{m}^{2}\right)\end{array}$ & $\begin{array}{c}\Delta \mathrm{E}^{*} \\
\left(2700 \mathrm{~kJ} / \mathrm{m}^{2}\right)\end{array}$ & $\begin{array}{c}\Delta \mathrm{E}^{*} \\
\left(3600 \mathrm{~kJ} / \mathrm{m}^{2}\right)\end{array}$ & $\begin{array}{c}\Delta \mathrm{E}^{*} \\
\left(4500 \mathrm{~kJ} / \mathrm{m}^{2}\right)\end{array}$ \\
\hline $\begin{array}{l}\text { Restauro Colore a Vernice } \\
\text { per Restauro 018 }\end{array}$ & 1,9 & 1,9 & 2,5 & 1,9 & 1,8 \\
\hline $\begin{array}{l}\text { Restauro Colore a Vernice } \\
\text { per Restauro 020 }\end{array}$ & 1,4 & 2,1 & 2,2 & 1,5 & 1,7 \\
\hline Renesans Colori a Vernice Nr. 1 & 0,6 & 0,4 & 1,4 & 0,3 & 0,3 \\
\hline Renesans Colori a Vernice Nr. 2 & 0,5 & 1,4 & 0,7 & 0,3 & 0,7 \\
\hline Van Gogh 104 & 0,9 & 0,7 & 1,5 & 0,9 & 1,1 \\
\hline Louvre 013 & 0,5 & 0,6 & 1,0 & 0,6 & 0,8 \\
\hline Decorlack 070 & 2,3 & 2,7 & 3,5 & 3,2 & 3,4 \\
\hline Porcelain 070 & 1,4 & 1,9 & 2,1 & 2,1 & 2,5 \\
\hline GlasArt 470 & 5,4 & 8,0 & 9,9 & 11,6 & 13,5 \\
\hline Gamblin 8081050 & 0,6 & 0,6 & 0,8 & 0,2 & 0,2 \\
\hline Kremer 4600090 & 1,4 & 1,7 & 1,9 & 2,1 \\
\hline Kremer 4620090 & 0,3 & 0,3 & 0,3 \\
\hline
\end{tabular}

Spośród badanych farb najmniejszą trwałość koloru wykazała GlasArt 470. Zżółknięcie jest bardzo widoczne już po pierwszej dawce naświetlania $\left(900 \mathrm{~kJ} / \mathrm{m}^{2}\right)$. Determinuje je budowa chemiczna spoiwa, w skład którego wchodzi olej. Relatywnie duże zmiany odnotowano instrumentalnie także dla kolejnych dwóch produktów Marabou GmbH \& Co. - Decorlack 070 oraz Porcelain 070, jednak ich uchwycenie nieuzbrojonym okiem jest niepewne. Stopień zażółcenia pozostałych powłok, mimo zarejestrowanych zmian barwy w układzie CIE LAB, jest niezauważalny. Przemiany fotochemiczne mogą być inicjowane przez każdy ze składników, który znajduje się w analizowanym układzie. 
Oprócz doboru spoiwa o dużej stabilności na promieniowanie ultrafioletowe, istotnym elementem jest aplikacja preparatu powłokotwórczego powinna się ona odbywać w optymalnych warunkach, pozwalających na pozbycie się resztek rozpuszczalnika i/lub rozcieńczalnika z układu. Drugim czynnikiem jest zastosowanie odczynników o dużej klasie czystości, gdyż nawet najmniejsza ilość zanieczyszczeń może wpłynąć na jakość powłoki.

Stabilność badanych układów na działanie promieniowania ultrafioletowego (tab. 6), nawet opartych na żywicach ketonowych i mastyksowych, które są bardzo podatne na żółknięcie, jest prosta do wyjaśnienia i opiera się na działaniu pigmentów bieli zawartych w farbach jako substancji ekranują$\mathrm{cych}^{25}$ oraz na efekcie barierowym ${ }^{26}$.

Ochronne działanie pigmentów jako substancji ekranujących w warstwach przypowierzchniowych wynika ze zjawiska rekombinacji, to jest wzbudzenia elektronów w wyniku absorpcji fotonów, a następnie emisji kwantu promieniowania z utworzeniem pary: ujemnie naładowany elektron i dodatnio naładowany nośnik ładunku - indywiduum określanego terminem dziury elektronowej. Proces wzbudzenia cząstek pigmentu zostaje zainicjowany w momencie gdy energia słoneczna dociera do jego powierzchni. Pod jej wpływem wybijane są elektrony, które w kontakcie z cząsteczkami tlenu tworzą jego nowe reaktywne formy (reactive oxygen species - ROS), takie jak $\cdot \mathrm{O}_{2}^{-}$(anionorodnik ponadtlenkowy) lub $\mathrm{H}_{2} \mathrm{O}_{2}$ (nadtlenek wodoru). Dodatnio naładowana powierzchnia pigmentu, chcąc powrócić do równowagi energetycznej, pozyskuje elektrony z wody zawartej w powietrzu. Skutkiem tego

25 Emad Yousif i Raghad Haddad, "Photodegradation and Photostabilization of Polymers, Especially Polystyrene”, SpringerPlus 2 (2013): 398 - 460, DOI: 10.1186/2193-1801-2-398; Mahmoud A. Salem, "Mechanical Properties of UV-Irradiated Low-Density Polyethylene Films Formulated with Carbon Black and Titanium Dioxide”, Egyptian Journal of Solids 24 (2001): 141-150; Ciabach, Żywice, 60-73.

26 Sarat K. Swain, Gyanaranjan Prusty i Itishree Jena, "Conductive, Gas Barrier, and Thermal Resistant Behavior of Poly(methyl methacrylate) Composite by Dispersion of $\mathrm{ZrO} 2$ Nanoparticles", International Journal of Polymeric Materials and Polymeric Biomaterials 62 (2013): 733-736, DOI: 10.1080/00914037.2013.769234; Deanna N. Busick, Richard J. Spontak i C. Maurice Balik, "Effects of Graphite Content on the Morphology and Barrier Properties of Poly(vinylidene fluoride) Composites”, Polymer 40 (1999): 6023-6029, DOI: 10.1016/S0032-3861(98)00826-X; Rishikesh K. Bharadwaj, “Modeling the Barrier Properties of Polymer-Layered Silicate Nanocomposites”, Macromolecules 34 (2001): 9189-9192, DOI: 10.1021/ma010780b. 
jest powstanie rodników hydroksylowych $(\cdot \mathrm{OH}) \mathrm{z}$ odtworzeniem cząsteczki tlenku metalu ${ }^{27}$.

Natomiast efekt barierowy polega na utrudnieniu dyfuzji szkodliwych czynników, w szczególności tlenu, w głąb masy polimerowej (rys. 3). Matryca polimerowa w farbach zostaje wypełniona (zmodyfikowana) cząstkami pigmentu. Wbudowane w spoiwo cząstki napełniacza działają jak naturalna przeszkoda, powodując w ten sposób wydłużenie czasu penetracji reaktywnych cząstek w głąb związku wielkocząsteczkowego.

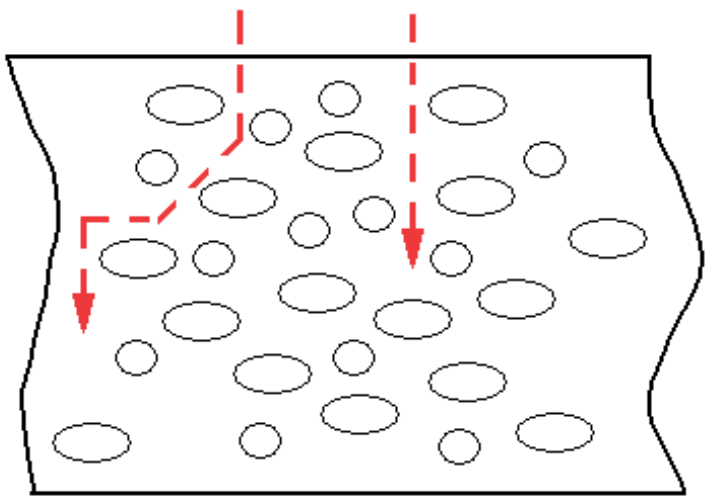

Rys. 3. Wydłużenie drogi dyfuzji w matrycy polimerowej wskutek omijania drobin napełniacza. Rys. Andrzej Podgórski

\section{Analiza w podczerwieni}

Do analizy w podczerwieni wykorzystano spektrometr model Alpha-P firmy Bruker. Widma FT-IR zarejestrowano z użyciem przystawki odbiciowej ATR z kryształem diamentowym, jako średnią ze stu dwudziestu ośmiu skanów. Zakres pomiarowy urządzenia wynosił $4000-400 \mathrm{~cm}^{-1}$, natomiast rozdzielczość to $4 \mathrm{~cm}^{-1}$.

27 Zhang Jinhui et al., "The Progress of TiO2 Photocatalyst Coating“, Journal of Engineering 2, no. 8 (2012): 50-53, Dostęp 20 lutego 2017; Hongying Yang, Sukang Zhu i Ning Pan, "Studying the Mechanisms of Titanium Dioxide as Ultraviolet-Blocking Additive for Films and Fabrics by an Improved Scheme”, Journal of Applied Polymer Science 92 (2004): 3201-3210, DOI: 10.1002/app.20327; James C. Moore, Robert Louder i Cody V. Thompson, "Photocatalytic Activity and Stability of Porous Polycrystalline ZnO Thin-Films Grown via a Two-Step Thermal Oxidation Process”, Coatings 4 (2014): 651-669, DOI:10.3390/coatings4030651. 

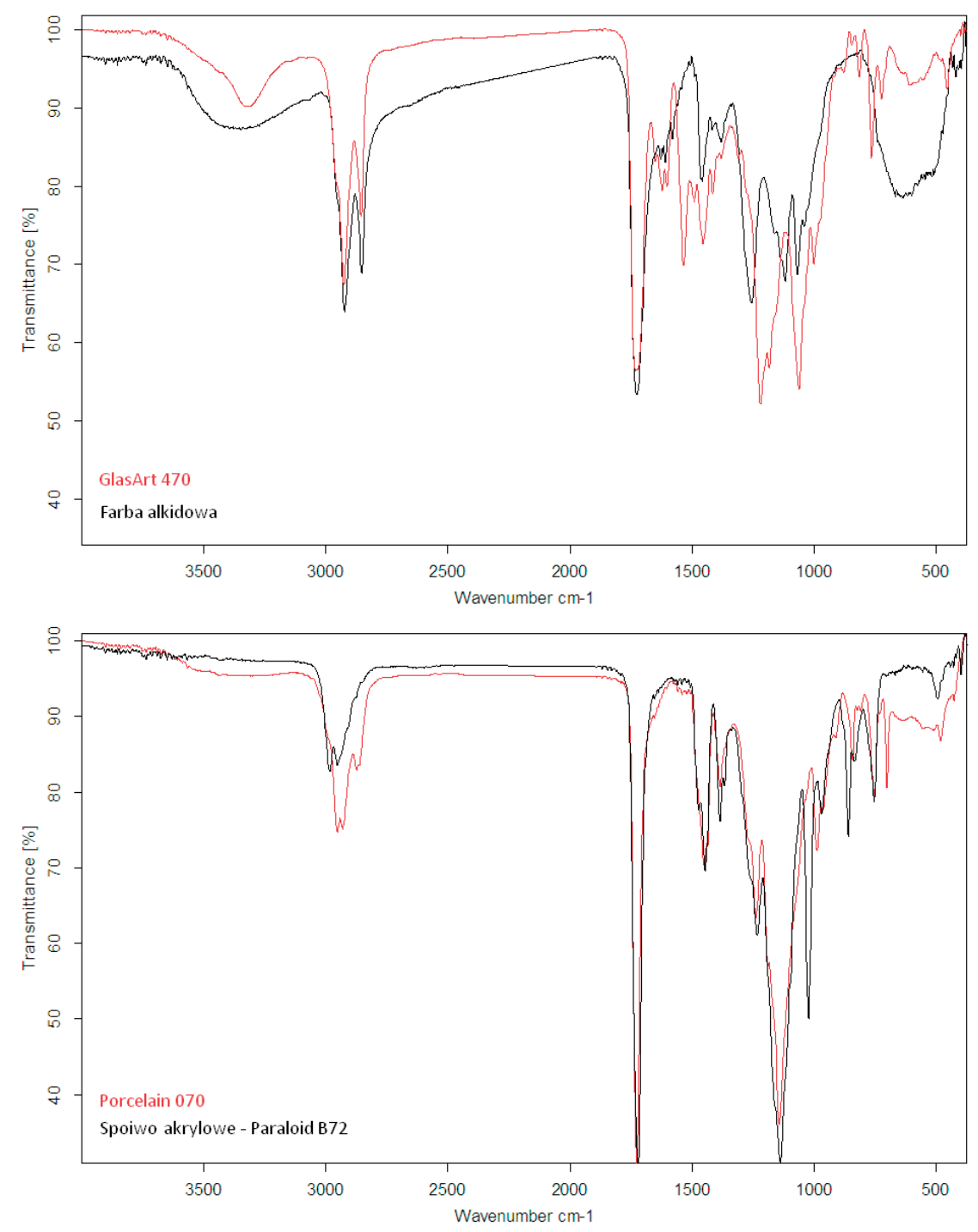

Rys. 4. Identyfikacja spoiw na podstawie analizy w podczerwieni. Rys. Wiesława Topolska

Na podstawie analizy widm FTIR-ATR (rys. 4) i porównania uzyskanych wyników z widmami wzorcowymi znajdującymi się w bazie dostarczonej wraz z oprogramowaniem do urządzenia stwierdzono, że spoiwo w farbie GlasArt 470 pochodzi z grupy alkidowych (Dekoral ${ }^{\circledR}$, Polska). Pojawienie się nowych sygnałów na widmie, ale przede wszystkim przesunięcia (poniżej $1800 \mathrm{~cm}^{-1}$ ) w porównaniu do wzorca (rys. 4) świadczą o silnych oddziaływaniach między 
składnikami układu oraz uzależnione są od gatunku i ilości oleju użytego do modyfikacji spoiwa. Natomiast Porcelain 070 bazuje na spoiwie akrylowym (wzorzec stanowił Paraloid B-72).

Zmiany, jakie odnotowano na spektrofotometrze MiniScan XE Plus, potwierdzono analizą w podczerwieni, największe dla GlasArt 470. Na widmach absorpcyjnych barwnych kompozycji (rys. 5) występują charakterystyczne pasma przypisane drganiom grup chemicznych.
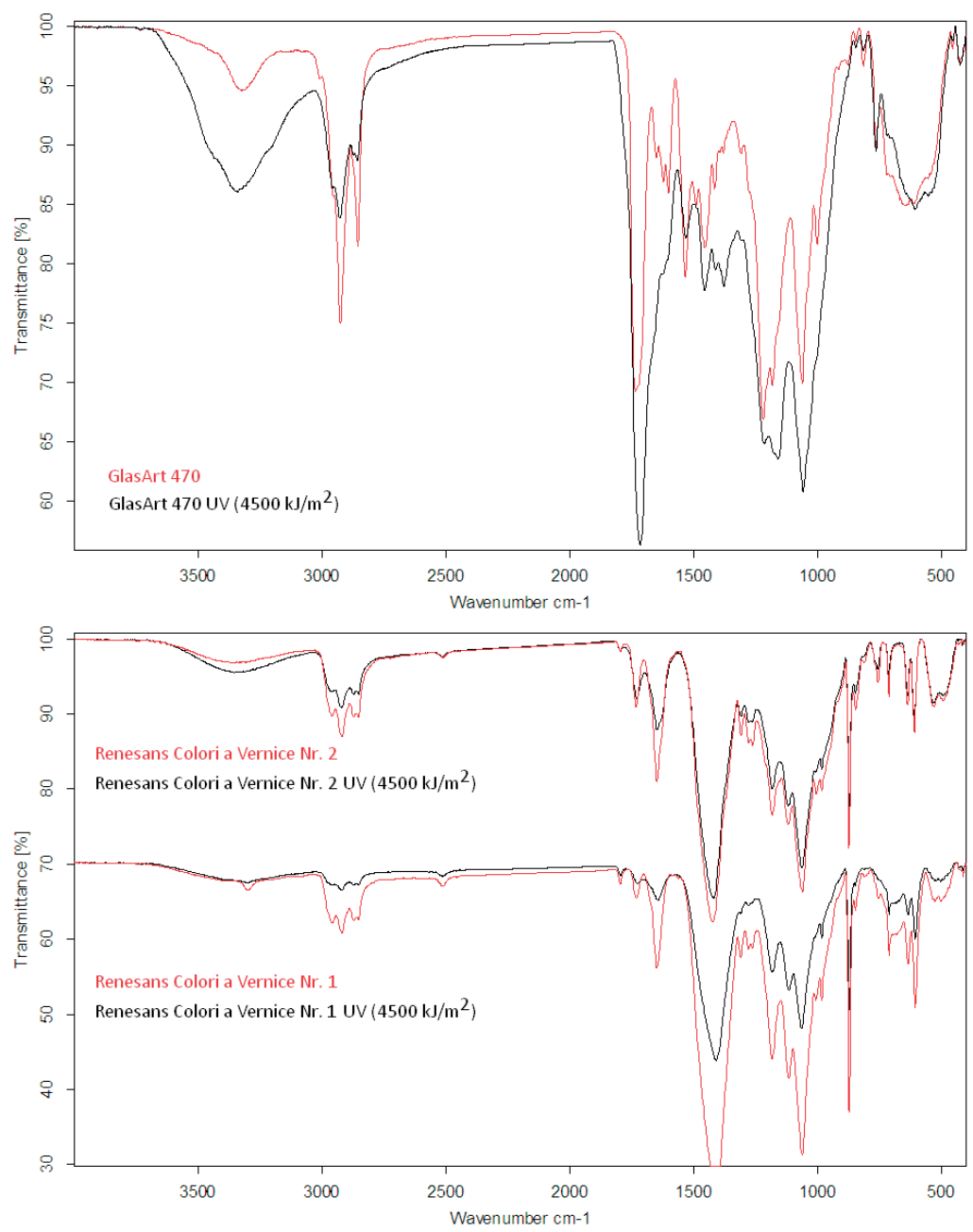

Rys. 5. Zmiany wywołane promieniowaniem UV w preparatach powłokotwórczych zarejestrowane techniką FTIR. Rys. Wiesława Topolska 
Zmiany intensywności integralnej bądź szerokości połówkowej wywołane promieniowaniem ultrafioletowym na widmach absorpcyjnych FTIR obserwowano przede wszystkim w paśmie pochodzącym od grup karbonylowych (w zakresie 1600-1800 $\mathrm{cm}^{-1}$ ), a także w paśmie ugrupowań hydroksylowych (w zakresie $3010-3680 \mathrm{~cm}^{-1}$ ), co świadczy o procesach fotoutleniania i/lub fotodestrukcji, które można w prosty sposób przedstawić schematycznie (rys. 6). Relatywnie duże zmiany intensywności integralnej pod pasmem pochodzącym od grup karbonylowych wskazują, że proces fotoutleniania w próbkach GlasArt 470 przebiega z większą wydajnością aniżeli w pozostałych. Jest to spójne z wynikami uzyskanymi z kolorymetru.

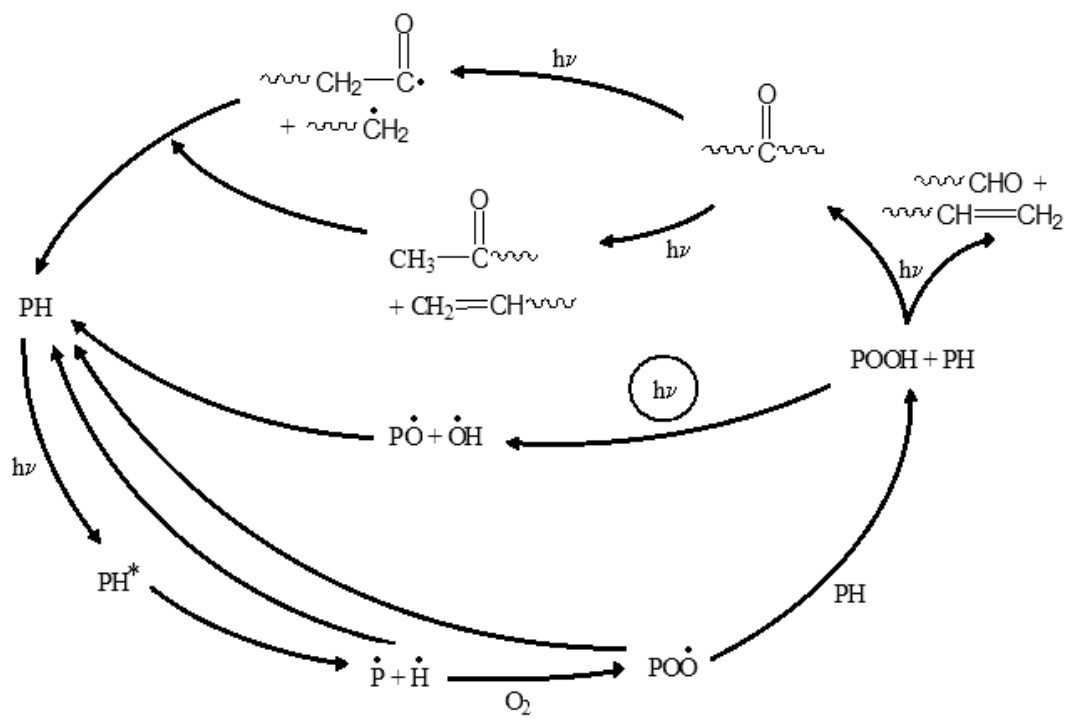

Rys. 6. Ogólny mechanizm przebiegu fotodegradacji polimerów. Rys. Andrzej Podgórski

\section{Wnioski}

Przeprowadzone badania farb retuszerskich mogą stanowić uzupełnienie dotychczasowego stanu wiedzy. W publikacjach duży nacisk położony jest na stabilność barwy oraz odwracalność preparatów powłokotwórczych, co jest $\mathrm{w}$ pełni zrozumiałe $\mathrm{z}$ konserwatorskiego punktu widzenia. Brakuje w nich 
jednak badań właściwości mechanicznych, które również winny stanowić istotne kryterium prawidłowego doboru materiałów do renowacji zabytkowych obiektów.

Badania na ogół potwierdziły przydatność handlowych wyrobów powłokotwórczych do scalenia kolorystycznego lub rekonstrukcji powłoki emalierskiej. W zależności od struktury i natury chemicznej spoiw obserwuje się zróżnicowanie właściwości mechanicznych uzyskanych powłok. W wyniku naświetlania próbek nie odnotowano - z wyjątkiem farby GlasArt 470 - wyraźnych zmian, dostrzegalnych nieuzbrojonym okiem, w barwie analizowanych powłok. Jednakże badania przeprowadzono na farbach, które zawierały wyłącznie dodatki bieli, czyli substancji przeciwdziałających promieniowaniu ultrafioletowemu. Uzyskanych wyników nie należy zatem utożsamiać z pełną gamą kolorystyczną pochodzącą od danego producenta.

Reasumując, najlepszym wyborem wydają się preparaty Kremer Pigmente $\mathrm{GmbH}$ \& Co. oraz Gamblin Conservation Colors, które charakteryzują się zadowalającą stabilnością barwy oraz dobrą adhezją wytworzonego cienkiego filmu do kompozytu służącego do uzupełniania ubytków.

\section{Imitatorskie uzupełnienia dekoracji emalierskiej}

Program prac konserwatorskich dotyczących emaliowanej w technice malarskiej misy do wody, należącej do zbiorów Muzeum Pałacu Króla Jana III w Wilanowie (nr inw. Wil. 258), obejmował odtworzenie warstwy dekoracyjnej. Emalia została w dużym stopniu uszkodzona pod wpływem czynników mechanicznych oraz długotrwałego działania wody (fot. 1: A), dlatego konieczne było przywrócenie obiektowi waloru ekspozycyjnego ${ }^{28}$.

W pierwszym etapie uzupełniono ubytki emalii kompozytem epoksydowym na bazie żywicy Eurostac EP-IN 2501. Jako wypełniacz zastosowano suspensyjny polimetakrylan metylu. Po opracowaniu powierzchni uzupełnień przeprowadzono ich unifikację kolorystyczną (fot. 1: B). Do wykonania tego zabiegu użyto farb retuszerskich na bazie Paraloidu B-72 firmy Kremer Pigmente GmbH \& Co. KG w kompozycji rozpuszczalników: 4 cz. eteru monometylowego glikolu propylenowego i $1 \mathrm{cz}$. mieszaniny izomerów eteru monometylowego glikolu dipropylenowego.

28 Opis techniki wykonania oraz stanu zachowania zob. Piasecka, Podgórski i TomaszewskaSzewczyk, „Metody imitatorskie”, 273-298. 

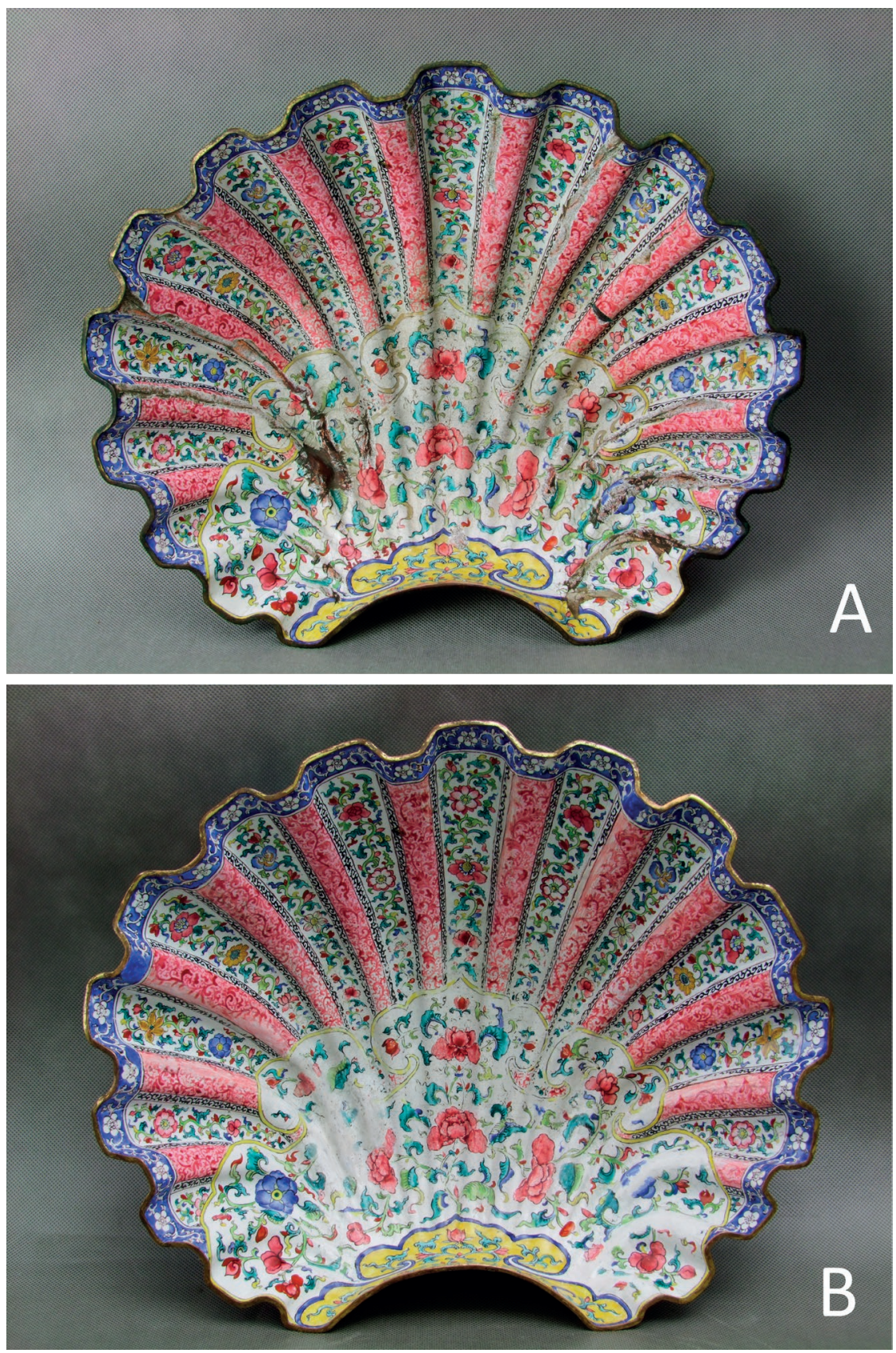

Fot. 1. Muzeum Pałac Króla Jana III w Wilanowie. Misa do wody, nr inw. Wil. 258. Fot. Alina Tomaszewska-Szewczyk

A - stan przed konserwacją; B - stan po konserwacji 


\section{Bibliografia}

Barkoula, Nektaria, i Jozsef Karger-Kocsis. "Review Processes and Influencing Parameters of the Solid Particle Erosion of Polymers and Their Composites”. Journal of Materials Science 37, no. 18 (2002): 3807-3820. DOI: 10.1023/A:1019633515481.

Basim, Aseel, Abdul Hussein, Fadhle Abbas Hashim, i Tamara Raad Khadhim. „Erosion Wear Behavior of Micro Material Reinforced Polymer Composites”. International Journal of Scientific \& Engineering Research 7 (2016): 972-984, www.ijser.org/researchpaper/Erosion-Wear-behavior-of-Micro-material-Reinforced-polymer-composites.pdf. Dostęp 20 lutego 2017.

Bharadwaj, Rishikesh K. "Modeling the Barrier Properties of Polymer-Layered Silicate Nanocomposites”. Macromolecules 34 (2001): 9189-9192. DOI: 10.1021/ma010780b.

Busick, Deanna N., Richard J. Spontak, i C. Maurice Balik. “Effects of Graphite Content on the Morphology and Barrier Properties of Poly(vinylidene fluoride) Composites”. Polymer 40 (1999): 6023-6029. DOI: 10.1016/S0032-3861(98)00826-X.

Ciabach, Jerzy. Żywice i tworzywa sztuczne stosowane $w$ konserwacji zabytków. Toruń: Wydawnictwo UMK, 1998.

Epacher, Edina, János Tolveth, Christoph Króhnke, i Bèla Pukanszky. "Pocessing Stability of High Density Polyethylene: Effect of Adsorbed and Dissolved Oxygen”. Polymer 41 (2000): 8401-8408. DOI: 10.1016/S0032-3861(00)00191-9.

Gijsman, Pieter, Guido Meijers, i Giacomo Vitarelli. “Comparsion of the UV-Degradation Chemistry of Polypropylene, Polyethylene, Polyamide 6 and Polybutyleneterephtalate”. Polymer Degradation and Stability 65 (1999): 433-441. DOI:10.1016/S01413910(99)00033-6.

Gronowska, Janina. Podstawy fizykochemii barwników. Toruń: Wydawnictwo UMK, 1989.

Gupta, Gaurav, i Alok Sata. "Processing, Characterization, and Erosion Wear Characteristics of Borosilicate Glass Microspheres Filled Epoxy Composites”. Polymer Composites 36, no. 9 (2015): 1685-1692. DOI: 10.1002/pc.23079.

Jinhui, Zhang, Li Si, Chen Long, Pan Yi, i Yang Shuangchun. "The Progress of TiO2 Photocatalyst Coating“. Journal of Engineering 2, no. 8 (2012): 50-53. Dostęp 20 lutego 2017.

Kotnarowska, Danuta. "Effect of Nanofillers on Wear Resistance of Polymer Coatings”. Solid State Phenomena 144 (2009): 285-290. DOI: 10.4028/www.scientific.net/ SSP.144.285.

Moore, James C., Robert Louder, i Cody V. Thompson. "Photocatalytic Activity and Stability of Porous Polycrystalline ZnO Thin-Films Grown via a Two-Step Thermal Oxidation Process". Coatings 4 (2014): 651-669. DOI:10.3390/coatings4030651.

Ochrimenko, Iłłarion S., i Władimir W. Wierchołancew. Chemia i technologia substancji błonotwórczych. Tłum. J. Urbański. Warszawa: WN-T, 1982.

Piasecka, Arletta, Andrzej Podgórski, i Alina Tomaszewska-Szewczyk. „Metody imitatorskie uzupełniania dekoracji emalierskiej: zastosowanie kompozytów polimero- 
wych na bazie żywic epoksydowych”. Acta Universitatis Nicolai Copernici, Zabytkoznawstwo i Konserwatorstwo 47 (2016): 273-298. DOI: http://dx.doi.org/10.12775/ AUNC_ZiK.2016.010.

Rabek, Jan F. Polimery. Otrzymywanie, metody badawcze, zastosowanie. Warszawa: Wydawnictwo Naukowe PWN, 2013.

Salem, Mahmoud A. "Mechanical Properties of UV-Irradiated Low-Density Polyethylene Films Formulated with Carbon Black and Titanium Dioxide”. Egyptian Journal of Solids 24 (2001): 141-150. Dostęp 20 lutego 2017.

Schnabel, Wolfram. Polymer Degradation Principles and Practical Applications. Berlin: Akademie-Verlag, 1981.

Swain, Sarat K., Gyanaranjan Prusty, i Itishree Jena. “Conductive, Gas Barrier, and Thermal Resistant Behavior of Poly(methyl methacrylate) Composite by Dispersion of ZrO2 Nanoparticles”. International Journal of Polymeric Materials and Polymeric Biomaterials 62 (2013): 733-736. DOI: 10.1080/00914037.2013.769234.

Szczepaniak, Walenty. Metody instrumentalne w analizie chemicznej. Warszawa: Wydawnictwa Naukowe PWN 1997.

Szmit-Naud, Elżbieta. „Farby dla konserwatorów malarstwa - właściwości aplikacyjne i stabilność”. Ochrona Zabytków 60 (2007): 59-68. http://cejsh.icm.edu.pl/cejsh/ element/bwmeta1.element.a539ce49-0747-3d2b-b089-4ed3a5a00fa5. Dostęp 20 lutego 2017.

Szmit-Naud, Elżbieta. “Uzupełnienia ubytków warstwy malarskiej obrazów: badania materiałów stosowanych współcześnie”. Acta Universitatis Nicolai Copernici, Zabytkoznawstwo i Konserwatorstwo 34 (2005): 65-102. oai:kpbc.umk.pl:23634. Dostęp 20 lutego 2017.

Tarasiuk, Jacek. Problemy barwy i koloru. home.agh.edu.pl/ tarasiuk/dydaktyka/doc/GFK/S/03.pdf. Dostęp 20 marca 2017.

Yang, Hongying, Sukang Zhu, i Ning Pan. "Studying the Mechanisms of Titanium Dioxide as Ultraviolet-Blocking Additive for Films and Fabrics by an Improved Scheme”. Journal of Applied Polymer Science 92 (2004): 3201-3210. DOI: 10.1002/app.20327.

Yousif, Emad, i Raghad Haddad. "Photodegradation and Photostabilization of Polymers, Especially Polystyrene”. SpringerPlus 2 (2013): 398 - 460. DOI: 10.1186/2193-18012-398.

Żuchowska, Danuta. Polimery konstrukcyjne. Warszawa: WN-T, 2000. 